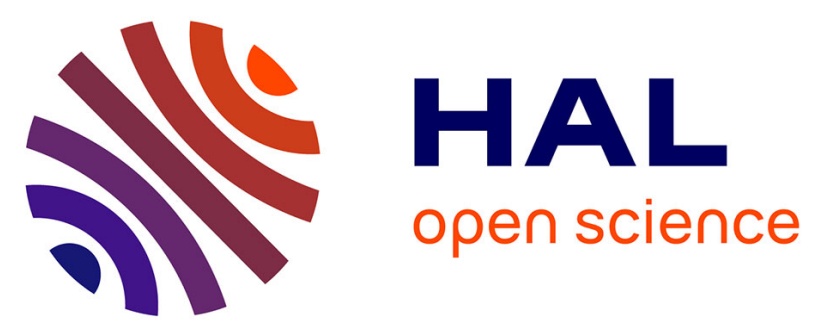

\title{
Review on Toll-Like Receptor Activation in Myasthenia Gravis: Application to the Development of New Experimental Models
}

Marieke Robinet, Solène Maillard, Mélanie A. Cron, Sonia Berrih-Aknin, Rozen Le Panse

\section{To cite this version:}

Marieke Robinet, Solène Maillard, Mélanie A. Cron, Sonia Berrih-Aknin, Rozen Le Panse. Review on Toll-Like Receptor Activation in Myasthenia Gravis: Application to the Development of New Experimental Models. Clinical Reviews in Allergy and Immunology, 2017, 52 (1), pp.133-147. 10.1007/s12016-016-8549-4 . hal-01321397

\section{HAL Id: hal-01321397 https://hal.sorbonne-universite.fr/hal-01321397}

Submitted on 25 May 2016

HAL is a multi-disciplinary open access archive for the deposit and dissemination of scientific research documents, whether they are published or not. The documents may come from teaching and research institutions in France or abroad, or from public or private research centers.
L'archive ouverte pluridisciplinaire HAL, est destinée au dépôt et à la diffusion de documents scientifiques de niveau recherche, publiés ou non, émanant des établissements d'enseignement et de recherche français ou étrangers, des laboratoires publics ou privés. 
REVIEW ON TOLL-LIKE RECEPTOR ACTIVATION IN MYASTHENIA GRAVIS: APPLICATION TO THE DEVELOPMENT OF NEW EXPERIMENTAL MODELS

Marieke Robinet ${ }^{1-4}$, Solène Maillard ${ }^{1-4}$, Mélanie A. Cron ${ }^{1-4}$, Sonia Berrih-Aknin ${ }^{1-4}$ and Rozen

Le Panse ${ }^{1-4}$

${ }^{1}$ INSERM U974, Paris, France

${ }^{2}$ CNRS FRE3617, Paris, France

${ }^{3}$ Sorbonne Universités, UPMC Univ Paris 06, Paris, France

${ }^{4}$ AIM, Institut de myologie, Paris, France

Correspondence: Rozen Le Panse

UMRS 974 UPMC - INSERM - FRE 3617 CNRS - AIM

Center of Research in Myology

105, Boulevard de l'Hôpital

75651 PARIS Cedex 13 - FRANCE

Tel 0033 (0)1 $40778127 \quad$ Fax 0033 (0)1 40778129

rozen.lepanse@upmc.fr

Key words: Autoimmune diseases, Inflammation, Innate immunity, Mouse experimental models, Complete Freund's adjuvant, Interferon type-I.

$\begin{array}{lll}\text { Abbreviations: } & \text { AChR: } & \text { acetylcholine receptor } \\ & \text { CFA: } & \text { complete Freund's adjuvant } \\ & \text { EAMG: } & \text { experimental autoimmune myasthenia gravis } \\ \text { EBV: } & \text { Epstein-Barr virus } \\ \text { EOMG: } & \text { early-onset MG } \\ \text { GC: } & \text { germinal center } \\ \text { IFA: } & \text { incomplete Freund's adjuvant } \\ \text { IFN: } & \text { interferon } \\ \text { IL: } & \text { interleukin } \\ \text { IRF: } & \text { IFN-regulatory factor } \\ \text { KO: } & \text { knock-out } \\ \text { MG: } & \text { myasthenia gravis } \\ \text { MyD88: } & \text { myeloid differentiation primary response gene } 88 \\ \text { PBMCs: } & \text { peripheral blood mononuclear cells } \\ \text { Poly(I:C): } & \text { polyinosinic-polycytidylic acid } \\ \text { TEC: } & \text { thymic epithelial cell } \\ \text { TLR: } & \text { toll-like receptor } \\ \text { TRIF: } & \text { TIR domain-containing adapter-inducing interferon- } \beta \text {. }\end{array}$




\section{Abstract}

Abnormal toll-like receptor (TLR) activation and uncontrolled resolution of inflammation are suspected to play a key role in the development of autoimmune diseases. Acquired myasthenia gravis (MG) is an invalidating neuromuscular disease leading to muscle weaknesses. MG is mainly mediated by anti-acetylcholine receptor (AChR) autoantibodies and thymic hyperplasia characterized by ectopic germinal centers is a common feature in MG. An abnormal expression of certain TLRs is observed in the thymus of MG patients associated with the overexpression of interferon (IFN)- $\beta$, the orchestrator of thymic changes in MG.

Experimental models have been developed for numerous autoimmune diseases. These models are induced by animal immunization with a purified antigen solubilized in complete Freund's adjuvant containing heat-inactivated mycobacterium tuberculosis (MTB). Sensitization against the antigen is mainly due to the activation of TLR signaling pathways by the pathogen motifs displayed by MTB and attempts have been made to substitute the use of CFA by TLR agonists. AChR emulsified in CFA is used to induce the classical experimental autoimmune MG model (EAMG). However, the TLR4 activator lipopolysaccharide (LPS) has proved to be efficient to replace MTB and induce a sensitization against purified AChR. Poly(I:C), the well-known TLR3 agonist, is also able by itself to induce MG symptoms in mice associated with early thymic changes as observed in human MG.

In this review, we discuss the abnormal expression of TLRs in MG patients and we describe the use of TLR agonists to induce EAMG in comparison with other autoimmune experimental models. 


\section{Role of thymic inflammation in myasthenia gravis development}

\subsection{Introduction on myasthenia gravis}

Autoimmune Myasthenia Gravis (MG) is a neuromuscular disorder characterized by a defective transmission of nerve impulses to muscles. This defect is caused by an autoimmune attack against components of the neuromuscular junction on the postsynaptic membrane of striated skeletal muscles. Around 85 to 90 percent of MG patients have autoantibodies against the acetylcholine receptor (AChR) [1]. The other smaller groups of MG patients display autoantibodies against the muscle specific kinase (MuSK) [2] or the low density lipoprotein related protein 4 (LRP4) [3] and even against agrin [4].

The characteristic feature of all MG forms is a fluctuating fatigable muscle weakness, which can range from a mild form affecting the eye muscles only to a severe form involving respiratory muscles [5]. Patients with anti-AChR antibodies can be divided into subgroups according to the age of onset. In these patients, histological abnormalities are very often found in the thymus, which displays either thymic hyperplasia of lympho-proliferative origin in EOMG or thymoma in late-onset MG [6] [7]. In contrast, the thymus of MuSK-MG patients shows no pathological changes and beneficial effects of thymectomy have not been proven for this subgroup [8] [9]. There is still no clear information on the involvement of the thymus in the LRP4-MG.

\subsection{Thymic abnormalities observed in MG patients}

The thymus provides an essential and complex environment for the generation of the Tcell repertoire. The differentiation of thymocytes occurs through interactions with stromal cells while they are progressing in the different thymic compartments [10] [11]. Thymic epithelial cells (TECs) being the main thymic stromal cells. In thymic cortical regions, TECs mainly mediate the positive selection of thymocytes, while in medullary regions, TECs are 
involved in the negative selection of thymocytes. Medullary TECs express a wide range of tissue-specific antigens (TSAs) and mediate the depletion of autoreactive T cells [12]. Only a few thymocytes successfully pass the thymic selection and are exported to the periphery as CD4 or CD8 T cells where they will differentiate into different subsets.

In EOMG, the thymus is the site of profound structural alterations [6]. The main characteristics of MG thymuses are the development of ectopic GCs in perivascular spaces in medullary regions. However, active neoangiogenic processes are also observed in the thymus with the development of high endothelial venules (HEVs) around GCs, and of lymphatic vessels [13] [14] [1,15]. The thymus in EOMG displays all the characteristics of tertiary lymphoid organs [16] [17]. The hyperplastic thymus includes all the components of the anti-AChR response: AChR [18], B cells producing anti-AChR antibodies [19] [20], and anti-AChR autoreactive T cells [21]. Thymic hyperplasia is especially correlated with the anti-AChR antibody titers. All these observations support the role of the thymus in the pathogenesis of MG and thymectomy is often advised for AChR-MG patients, resulting in a decrease in anti-AChR antibodies [22] and a slow but effective improvement of symptoms over a few years [23] [9].

Thymic changes in MG are driven by the abnormal overexpression of chemokines such as CXCL13, CCL21, CCL19, CXCL12, CXCL10, CCL17 and CCL22 [24] [14] [25]. The implication of CXCL13 and CCL21 in thymic hyperplasia has been particularly studied as these two chemokines are involved in B-cell recruitment and GC development [26] [27]. CXCL13 is known to be produced by GCs in secondary lymphoid organs but in EOMG, CXCL13 is overexpressed by medullary TECs [28] [29] [30] and several indications suggest that CXCL13 could be involved in the recruitment of B cells: 1) thymic extracts from MG patients have a strong chemoattractive effect on B cells, 2) this effect is reduced when using anti-CXCL13 blocking antibodies and 3) the thymus of MG patients under corticotherapy 
shows a normalized level of CXCL13 together with a reduced number of GCs [28]. Moreover, thymic and serum levels of CXCL13 were shown to correlate with disease severity [28] [30] [31].

The active neoangiogenesis processes are also crucial in the recruitment of peripheral cells via interactions with chemokines. In EOMG patients, thymic HEVs selectively expressed CXCL12, and antigen presenting cells such as macrophages, DCs, and B cells expressing CXCR4 (the CXCL12 receptor), are detected inside and around thymic HEVs [15]. Thymic hyperplasia in MG patients is also specifically associated with the thymic overexpression of CCL21 and CCL19, two chemokines interacting with the CCR7 receptor. CCL21 overexpression in hyperplastic MG thymuses is due to lymphatic endothelial vessels that could also lead to a recruitment of peripheral cells, such as sensitized DCs but also T and B cells [13].

\subsection{Central role of type-I interferons in thymic changes}

The role of inflammatory cytokines is crucial for the autoimmune sensitization against AChR in the thymus of MG patients. Type-1 interferons (IFN-I) are pleiotropic cytokines involved in innate immune responses and the regulation of the pro-inflammatory responses. The implication of IFN-I in MG has long been suggested in various ways: 1) clinical reports demonstrate the development of MG after IFN- $\alpha$ - or - $\beta$-based therapies [32]; 2) antibodies against IFN- $\alpha$ are found in some MG patients, mainly those with thymoma [33]; [34]; and 3) a thymic transcriptome analyzis of different MG patient subgroups shows a significant increase in the expression of IFN-I-induced genes [35] [36]. IFN-I could directly affect TEC behavior but also thymocyte differentiation/activation. A study on peripheral blood mononuclear cells (PBMCs) demonstrates that a chronic elevation of IFN- $\alpha$ can modify the effector/regulatory $\mathrm{T}$ cell ratio towards effector $\mathrm{T}$ cells and autoimmunity [37]. 
Different IFN-I and IFN-III subtypes, but especially IFN- $\beta$, are overexpressed in the thymus of MG patients [38]. Analyzing in detail the in vitro effect of IFN- $\beta$, it is showed that IFN$\beta$ induces specifically the expression of $\alpha$-AChR and not that of other TSAs. It also increases TEC death and the uptake of TEC proteins by DCs. In parallel, IFN- $\beta$ triggers the expression of the chemokines CXCL13 and CCL21 by TECs and lymphatic endothelial cells, respectively. The B-cell activating factor (BAFF), which favors B-cell survival, is overexpressed by TECs in MG thymus and is also induced by IFN- $\beta$ in TEC cultures. Similar changes are observed in vivo. Polyinosine-Polycytidylic acid (Poly(I:C)) is a synthetic molecule mimicking double-stranded RNA (dsRNA) from viral infections. The injections of Poly(I:C) to C57BL/6 mice trigger the thymic overexpression of IFN- $\beta$ and IFN- $\alpha 2$ associated with increased expressions of CXCL13, CCL21, BAFF, and favor the recruitment of B cells. These changes are not observed in the thymus of IFN-I receptor knock-out (KO) mice injected with Poly(I:C), even if IFN- $\beta$ and IFN- $\alpha 2$ are overexpressed [39]. Altogether, these results demonstrate that IFN- $\beta$ could play a central role in thymic events leading to MG by triggering the overexpression of $\alpha$-AChR probably leading to thymic $\mathrm{DC}$ autosensitization, the abnormal recruitment of peripheral cells and GC formation as summarized in figure 1.

The critical role played by inflammation in thymic changes associated with EOMG is also put forwards thanks to a new study using a novel transgenic mouse model with a thymic overexpression of CXCL13. It is demonstrated that CXCL13 overexpression by itself is not sufficient to induce peripheral B-cell recruitment to the thymus. However, upon Poly(I:C) injections leading to thymic inflammation, CXCL13 triggered a strong recruitment of B cells to the thymus [40]. 
IFN-I subtypes may also play a central role in thymoma-associated MG. Indeed, huge increases of IFN- $\alpha 2,-\alpha 8,-\omega$ and to a lesser extend of IFN- $\beta$ are detected in thymomaassociated MG but not in thymoma without MG or in control thymuses. These results reinforce again a specific role of IFN-I and the anti-AChR response associated with $\mathrm{MG}$ [41]. The inflammatory environment characteristic of MG thymus, with IFN-I overexpression, could act at different thymic levels: the AChR expression by TECs, the sensitization against $\alpha$-AChR and consequently triggers an autoimmune response against AChR (Figure 1).

\subsection{Activation of innate immunity pathways in MG patients}

Autoimmune diseases are multifactorial diseases and in the last decade diverse environmental factors have been singled out to explain the emergence of these diseases [42]. Pathogens are major environmental-factor candidates for driving/perpetuating autoimmunity but it is difficult to link infections with the onset of the disease [43]. Indeed, symptoms related to autoimmune diseases occur probably long after the pathogen infection, when the pathogen might have already been cleared or the antiviral immune responses might have subsided ("hit-and-run" hypothesis) [43]. Nevertheless, accumulating evidences tend to support the contribution of pathogens in promoting, exacerbating, or maintaining autoimmune conditions.

The thymus is a common target organ for infectious diseases [44]. Striking evidence of chronic inflammation and emerging data on persistent viral infections in the thymus of MG patients strongly supports the hypothesis that the activation of the innate immune system may trigger or favor MG development. Bernasconi et al. describe poliovirus-infected macrophages and the presence of Epstein-Barr virus (EBV)-infected B cells in MG thymus [45] [46] [47]. The ability of EBV to infect and transform B-cells, allowing them to evade immune surveillance [47], makes it a prime suspect for chronic infection and inflammation. 
EBV could activate and immortalize intra-thymic autoantibody-producing cells and sustain chronic inflammation via TLR-mediated pathways [48].

As we observed in the MG thymus an anti-viral signature together with an increased expression of IFN-I-induced genes [29], we suggest that inappropriate activation of pathogen-signal pathways could be involved in thymic changes associated with MG.

\section{TLR: sensors of pathogen infections and implication in autoimmune MG}

\subsection{TLR signalization}

A major role in innate immunity is played by toll-like receptors (TLRs), a type of pattern recognition receptors (PRRs) able to recognize conserved microbial molecules. Each TLR recognizes specific microbial derived molecular structures [49]. 11 and 12 members of the TLR family have been identified in human and mouse, respectively. TLRs are essentially described in immune cells but can be found in various other cell types. TLR activation and signalization are largely described in diverse reviews [50] [51] [52]. Briefly, TLR1, TLR2, TLR4, TLR5, TLR6 and TLR10 are located on the cell surface and especially recognize microbial membrane components. TLR3, TLR7, TLR8, TLR9 and TLR11 are mainly located on the intracellular endosome membranes. Intracellular TLRs recognize nucleic acids derived from bacteria or viruses (Table 1). TLRs are delivered from the endoplasmic reticulum to the endosome by the endoplasmic reticulum-resident membrane protein UNC93B1.

The interaction with their ligands lead to TLR dimerization and internalization. Except TLR3, all TLRs interact with the intracellular adaptor MyD88 (myeloid differentiation primary response gene 88) and activate downstream signaling cascades. TLR3, but also TLR4, activate intracellular signaling pathways via TRIF (TIR domain-containing adapterinducing interferon- $\beta$ ). TLR2, TLR5 and TLR9 have also been described as being able to 
activate TRIF signaling pathway [53] [54] [55]. In all cases, TLR activation leads to the stimulation of the NF-kB, p38, JNK and/or IFN-regulatory factor (IRF) signaling pathways, resulting in the production of inflammatory cytokines and in particular IFN-I [56]. The activation of TLR signaling pathways is probably more complex than what has been so far described as TLRs are able to interact and form heterodimers that could enhance, inhibit or modulate more specifically the cell response according to the pathogens present in the local environment [50].

A lower amount of intracellular TLRs are also localized on the cell surface. In the case of TLR3, Pohar et al. demonstrate that the UNC93B1 protein promotes the translocation of a differentially glycosylated form of TLR3 to the cell surface. In addition to the translocation, UNC93B1 is upregulated upon Poly(I:C) treatment and enhances the responsiveness of TLR3 and TLR9 by increasing their lifetime. They hypothesize that TLR3 on cell surface could allow the detection of low amount of circulating dsRNA and potentiate the activation of TLR9 through the upregulation of UNC93B1 [57]. The other endosomal TLRs are also detected on the cell surface and for TLR9 it seems to act as a negative regulator of the Bcell response [58] [59] [60].

The first function of TLRs is to set up an innate immune response to protect the organism from pathogens. However studies, both in experimental settings and in a number of human autoimmune diseases, indicate that the loss of regulation of TLR signaling can lead to chronic inflammation and autosensitization, thereby promoting or favoring inflammatory and autoimmune diseases [61] [51]. The contribution of TLRs in autoimmunity can mainly be explained by the ability of these receptors to stimulate the maturation of antigenpresenting cells, the production of IFN-I and of other pro-inflammatory cytokines [49]. TLR3, TLR4, TLR7, TLR8 and TLR9 activation promotes Th1-type immune responses while signaling via TLR2 (along with TLR1 or TLR6) and TLR5 favors Th2-type immune 
responses [62]. TLR ligands also influence the development of regulatory T cells [63] and Th17 cells. Moreover, along with antigen binding to the B-cell receptor and CD40 stimulation, TLR stimuli, mainly those mediated by TLR3, TLR7 and TLR9, provide additional costimulatory signals for proliferation, maturation and survival of B-cells, including autoreactive B cells, thus compromising B-cell tolerance [64], [65] [66]. In vitro and in vivo studies suggested that persistent activation of nucleic acid-sensing TLRs, such as TLR7, TLR8 and TLR9 may cause systemic autoimmunity, through stimulation of B-cell activation and autoantibody production [67].

\subsection{Abnormal TLR activation in PBMCs of MG patients}

Abnormal expression of TLRs on PBMCs has been demonstrated in various autoimmune diseases. Wang et al. analyzed TLR mRNA expression in PBMCs from MG patients. While TLR7 expression is similar in MG and controls, TLR1, TLR6, and TLR10 are significantly downregulated and TLR2, TLR3, TLR4, TLR5, TLR8, and TLR9 are significantly upregulated in PBMCs from MG compared to healthy donors [68]. In the classical experimental autoimmune MG (EAMG) model, TLR4 expression is also found increased in AChR-specific B cells [69]. Of interest, the expression of TLR9 is positively correlated to the quantitative $\mathrm{MG}$ score (QMG) of patients. However, they do not observe a normalization of TLR expression in patients under methylprednisone treatment [68]. These changes in TLR expression could reflect changes in the percentage of specific peripheral cells in MG patients or a different activation state for PBMCs.

\subsection{Abnormal TLR expression in MG thymus}

The expression level of TLRs in the thymus of MG patients has been analyzed in different studies. These global analyzes reflect the implication of all thymic cells and do not detail which cells are implicated. Thymic stromal cells such as TECs and myoid cells express 
all TLRs [38]. In periphery immune cells express all TLRs at various degrees [70] but the expression of TLRs by thymocytes themselves has never been fully investigated.

By semiquantitative PCR measures, Bernasconi et al. first demonstrate the overexpression of TLR4 in MG thymus characterized by B cell infiltrations but not in hyperplastic MG thymuses. They do not observe changes for TLR2, TLR3 and TLR5 expression but threequarters of the MG patients included in the study were receiving immunosuppressive therapies that might affect the global level of TLR expression [71]. In another study, we demonstrate the overexpression of TLR3 in the thymus of MG patients [38] and no difference is observed between patients with a high or low degree of thymic hyperplasia suggesting that the higher TLR3 expression level is not linked to the increased number of B cells in hyperplastic thymuses. In parallel, we observed an increase in TLR3 expression in TEC cultures derived from the thymus of MG patients compared to controls (data not shown). This increased expression of TLR3 in MG thymus could reflect an abnormal activation subsequent to a viral infection. Moreover, TLR3 expression is detected in TECs and could be involved in the overexpression of IFN- $\beta$ in MG thymuses. In the same study, an increased expression of the protein kinase R (PKR), another dsRNA interacting protein, but not for RIG1 and MDA5 helicases is measured in MG thymuses [38]. Recently, Cavalcante et al. demonstrated the overexpression of TLR7 and TLR9 in the thymus of MG patients. By immunohistochemistry, a stronger expression of TLR7 and TLR9 is observed in B cells, TECs, plasmacytoid dendritic cells and macrophages in MG thymuses compared to controls. TLR7 is also increased in thymic myeloid dendritic cells and its transcriptional levels positively correlates with those of IFN- $\beta$ [72].

In order to have a global view on the expression levels of all TLRs in the thymus of MG patients, we carried out quantitative PCR on control thymuses compared to thymuses from MG patients with various degrees of thymic hyperplasia (Figure 2A). First, we observed that 
TLR1 to TLR9 were all expressed in control female thymuses with TLR1 and TLR9 being the most expressed and TLR8, TLR5 and TLR2 the less. We did not observe significant changes for TLR1, TLR2, TLR5 and TLR7 expression in untreated MG patients and controls. We confirmed the increased expression level of TLR3 for all MG patients [38]. We observed an increased expression for TLR4 but only in hyperplastic thymuses. For TLR3 and TLR4, the expression levels were even exacerbated in patients under corticoid treatment. We also demonstrated a specific overexpression for TLR6, TLR8 and TLR9 in hyperplastic MG thymuses suggesting a link with the presence of GCs, especially as the levels of expression were lowered in patients with corticoid treatments. Indeed, corticoids are known to decrease the number of GCs in MG thymuses [28]. Moreover, by analyzing the level of CD19 mRNA expression in these thymic biopsies, a significant correlation was observed between the level of CD19 mRNA expression and TLR6, TLR8 and TLR9 mRNA but not for TLR3 and TLR4 mRNA (Figure 2B).

To investigate the potential consequences of pathogen infection on the thymus, our team analyzed the effects of TLR agonists (from TLR1 to TLR9) on human TECs in culture. We demonstrated that Poly(I:C), a synthetic analog of dsRNA, specifically induces the thymic overexpression of $\alpha$-AChR, but not other AChR subunits or TSAs. This induction is mediated through TLR3, PKR and by the release of IFN- $\beta$ but is completely inhibited by IFN-I receptor or IFN- $\beta$ blocking antibodies [38].

If Poly(I:C) seems to specifically affect AChR expression by TECs, the activation of other TLR signaling pathways could also be crucial in sustaining the inflammatory response leading to MG development and the chronicity of the disease. The thymic EBV signature observed in MG thymuses could explain the activation of diverse TLR signaling pathways. Indeed, EBV dsDNA and RNA could account for TLR9 and TLR7 activation [73]. EBV also encodes small RNAs with a dsRNA-like structure (EBER) that can trigger TLR3 
signaling [74]. TLR2 is also suspected to play an important role in immune responses directed against EBV infection [75] but TLR2 expression was not up-regulated in MG patients (Figure 2A). Moreover, TLR7 activation can increase the expression of EBV latent membrane protein 1 (LMP1) in EBV-infected cells, and potentiates those cells for production of IFN-I by TLR3 or TLR9 activation [76].

\section{Role of TLR agonists in experimental autoimmune models: Focus on mouse MG} models

\subsection{The EAMG model based on AChR immunizations using CFA as adjuvant}

In almost all induced experimental models for autoimmune diseases, a purified antigen is injected emulsified in complete Freund's adjuvant (CFA) (Table 2). EAMG can be triggered by active immunization with $\mathrm{AChR}$ peptides, AChR subunits, recombinant fragments of muscle $\mathrm{AChR}$ or purified $\mathrm{AChR}$ isolated from electrical organs of torpedo fish (T-AChR) [77]. A guideline review has been recently published detailing thoroughly the mouse EAMG model [78]. Briefly, strains carrying the $\mathrm{H}-2 \mathrm{~b}$ haplotype are more susceptible to EAMG and the C57BL6 mouse strain is the conventional wild-type mouse strain used in most studies. For immunization, $20-30 \mu \mathrm{g}$ of T-AChR emulsified in CFA containing heatkilled and dried mycobacterium tuberculosis (MTB) is used [79]. A small volume of the emulsion is subcutaneously injected in several sites. For the first immunization, the injections are done in the hind foot-pads and in 4 to 6 sites on the back including the base of the tail. After 25-30 days, mice should be immunized a second time with the T-AChR in CFA or IFA (incomplete Freund's adjuvant) emulsions but only in sites on the back. After the second immunization, around 50-60 \% of the mice develop EAMG symptoms. If the EAMG incidence is less than $50 \%$, a third immunization with T-AChR in IFA can be done [78]. EAMG is easier to induce in rats as one immunization if sufficient in inducing strong MG symptoms [80]. 
As for many autoimmune experimental models, the use of CFA is mandatory to set up these disease models and MTB is critical in the activation of innate immune signaling pathways leading to the sensitization against the injected antigen. How CFA acts is not clearly defined even if it has been used since the fifties. CFA is composed of IFA (a paraffin oil) with added MTB. It is generally assumed that administering a protein antigen as a waterin-oil emulsion prolongs its lifetime at sites of injection leading to the formation of local and distant granulomas composed of mononuclear phagocyte cells and oil drops. Then a strong and long-lasting inflammatory reaction develops at sites of injection but also in draining lymph nodes. IFA on its own induces a Th2-dominated response compared to CFA which induces a Th1-dominated response [81]. CFA induces the expression of pro-inflammatory cytokines mainly tumor necrosis factor- $\alpha$, interleukin (IL)-12, IL-6, IFN- $\gamma$, and chemokines by mononuclear phagocyte cells and natural killer cells. The released cytokines ultimately lead to polyclonal activation of T cells and ultimately antigen-specific T cells. In the EAMG mouse model, CFA involves both a strong Th1 and a Th2 response, but also B-cell growth and differentiation associated with the secretion of $\operatorname{IgG} 2$ and IgG1 antibodies [82]. The IFA response in mice favors the production of IgG1 antibodies that do not bind the complement. In contrast, the predominant Th1 response induced by CFA favors the production of complement-binding antibody isotypes, such as IgG2b and IgG2c in C57BL/6 mice, that can be pathogenic and in the case of anti-AChR antibodies cause the destruction of AChR at the neuromuscular junction [83].

Heat-killed and dried MTB contained in CFA is central in inducing the sensitization against the injected antigen. MTB is responsible for tuberculosis. It is a pathogenic bacteria infecting and surviving in mononuclear cells. TLR2, TLR4, TLR9 and possibly TLR8 are able to interact with MTB pathogen patterns. TLR activation upregulates the transcription of proinflammatory cytokines which are essential for the recruitment of immune cells to the site 
of infection and the control of MTB infection. As a first line of defense, MTB infection triggers an innate immune response followed by an adaptive immune response to contain the infection. This is characterized by the development of antigen specific CD4+ T cells that secrete Th1 pro-inflammatory cytokines such as IFN- $\gamma$, and the activation of CD8+ T cells. Th1 and Th17 pro-inflammatory cytokines are most probably central to the development of the immune response against MTB and the development of autoimmune experimental models. Indeed, IFN- $\gamma$ KO and IL-17 KO mice are resistant to EAMG [84] [85] [86].

Even if it is evident that MTB infection activates TLR signaling pathways, the activation of these pathways by CFA itself is not completely proven. Gavin et al. showed that CFAenhanced antibody responses occur in MyD88 and TRIF (Trif Lps2/Lps2 mice)) KO mice, which cannot transmit signals through TLRs [87]. However, numerous studies have proven that MyD88 KO mice are less susceptible to experimental autoimmune models [88] [89] [90]. Specific TLR KO mice do not seem to be resistant to the induction of autoimmune experimental models and it was suggested by Fang et al. that TLR2, TRL3, TRL4, and TRL9 are highly redundant in transducing CFA adjuvant effect to induce the experimental autoimmune models [88] [91].

\subsection{Alternative use of other adjuvants to induce EAMG}

Different attempts have been made to use other adjuvants than CFA for the EAMG model. Indeed, only 50-60\% of the mice develops MG symptoms and CFA injections in foot pads can induce a local pain and consequently restrictions of national regulatory authorities. The induction of EAMG in mice without CFA was tried with the intraperitoneal injection of affinity-purified AChR prepared from the $\mathrm{BC} 3 \mathrm{H} 1$ cell lines. MG symptoms were observed but appears less effective and this method was not used afterwards [92] [93].

Milanui et al. describe a model where aluminum hydroxide is used instead of CFA to induce MG in C57BL/6 mice. Aluminum hydroxide is used for human vaccination. Its 
efficacy resides in its ability to induce the release of uric acid that is considered as a danger signal by the immune system. Aluminum hydroxide leads thus to the activation of monocytederived inflammatory cytokines improving the uptake of the antigen. Aluminum hydroxide induces mainly a Th2 response associated with IgG1 production [94]. Compared to mice immunized with TAChR/CFA and boosted in TAChR/IFA, mice immunized several times with TAChR/aluminum hydroxide develop milder EAMG symptoms and lower levels of anti-T-AChR or mouse-AChR antibodies. In aluminum hydroxide, mice produce essentially Th2 cytokines and anti-T-AChR IgG1 that are less pathogenic as they do not bind the complement. In fact, this study even demonstrates that anti-TAChR CD4+ T and B cells with a Th2 phenotype may cooperate in protecting mice from EAMG [82]. A similar observation was made by Oshima et al. that used an AChR peptide solubilized in aluminum hydroxide and killed pertussis organisms to vaccinate and protect C57BL/6 mice prior immunization with T-AChR in CFA [95].

A new adjuvant formulation was developed in the nineties as an alternative to CFA for producing antisera in animals. This adjuvant named Titermax is also a water-in-oil emulsion composed of a block copolymer, squalene (a metabolizable oil), and microparticulates. It has a lower toxicity than CFA and does not contain microbial products [96]. The use of this adjuvant for the induction of autoimmune experimental models is hardly described. Nevertheless, Titermax has been tested for its ability to induce EAMG. C57BL/6 mice were inoculated with T-AChR emulsified in Titermax. Mice immunized displayed characteristic MG muscle weakness with electrophysiological defect, elevated serum anti-AChR antibodies, and muscle AChR loss [97]. However, this new adjuvant was not used afterwards. 


\subsection{Alternative use of LPS instead of CFA to induce EAMG}

Bacterial lipopolysaccharides (LPS) are present on the surface of almost all gramnegative bacteria and act as extremely strong stimulators of innate immunity. LPS activate intracellular pathways through TLR4. TLR4 is expressed by various cells types and not only by immune cells. It is the only TLR that does not directly bind its ligand, and LPS stimulation of TLR4 includes the participation of other molecules. LPS first binds to the LPS binding protein (LBP) and can then interact with CD14 and subsequently with the TLR4/MD-2 receptor complex (TLR4 being a transmembrane protein and MD-2 a soluble protein). CD14 is a glycosylphosphatidylinositol-anchored protein, which also exists in a soluble form. If CD14 is mainly known to be expressed by macrophages, it can also be expressed at a lower level by cells of both hematopoietic and non-hematopoietic origin as a cell membrane or secreted proteins. Soluble CD14 could even allow the activation of TLR4 by LPS in CD14 negative cells. Ultimately, binding of LPS to CD14/TLR4/MD2 results in dimerization of the receptor complex and the activation of different signaling pathways is elicited through MyD88 and TRIF molecules [98] [99]. LPS effects through TLR4 activation is suspected to play a role in autoimmune diseases [100].

Allman et al. have used LPS as adjuvant instead of MTB in CFA to induce the EAMG model. C57BL/6 mice were immunized by several subcutaneous injections in foot pads and shoulders with T-AChR and LPS emulsified in IFA or T-AChR emulsified in CFA. Mice were immunized three times at days 0,28 and 56. AChR-LPS/IFA immunized mice develop clinical signs that are similar to those observed with the AChR/CFA immunization. They produce anti-AChR antibodies, and $\mathrm{IgG} 2$ and $\mathrm{C} 3$ deposits are detected at the neuromuscular junction. However, B-cell activation leading to the production of the anti-AChR antibodies is different in AChR-LPS/IFA and AChR/CFA models. Using CD4 ${ }^{-/-} \mathrm{KO}$ mice, they 
demonstrated that CFA immunization requires CD4 co-stimulation of B cells to induce antiAChR IgG2 secretion while LPS immunization does not.

Rose and collaborators also investigated the effect of LPS in the induction of the experimental thyroiditis model classically based on active immunization of mice with thyroglobulin emulsified in CFA. They observed that intravenous injections of LPS, in parallel to thyroglobulin injections, are sufficient to induce thyroglobulin-specific autoantibodies and inflammatory lesions in the thyroid gland [101]. LPS has also be successfully used as an adjuvant instead of CFA in the experimental autoimmune thyroiditis model. In this model, while CFA pathogenic effects are dependent on CD8 T cells, LPS effects are independent of CD8 T cells. LPS seems to enhance the immunogenicity of autoantigens but also to affect directly thyrocytes by inducing the expression of chemokines that could facilitate its lymphocytic infiltrations [102].

\subsection{A novel experimental MG model based on Poly(I:C) injections}

Poly(I:C) that mimics dsRNA from viral infections is well-known to interact with TLR3 but also PKR and RNA helicases (MAD5 and RIG-I) [103]. It has been demonstrated that dsRNA signaling induced by Poly(I:C) specifically triggers the overexpression of $\alpha$-AChR in human TECs and not the expression of other TSAs expressed by TECs. This induction is mediated through TLR3 and PKR, and by the release of IFN- $\beta$. Interestingly, the overexpression of TLR3, PKR, IRF-7, IRF-5, and IFN- $\beta$, which are all involved in antiviral responses induced by dsRNA, are also observed in the MG thymus [38].

On the basis of these observations, C57BL/6 mice were injected with $200 \mu \mathrm{g}$ of Poly(I:C) three times a week. After one week, specific changes are observed in the thymus of Poly(I:C) injected mice: increased expression of IFN- $\beta$, IFN- $\alpha 2$ and $\alpha$-AChR but also CXCL13 and CCL21 which are overexpressed in the MG thymus [28] [13]. In parallel, a recruitment of B cells is observed after Poly(I:C) injections. These thymic changes are not observed in IFN-I 
receptor $\mathrm{KO}$ mice, underlying the central role played by IFN-I in thymic changes associated with MG [38] [39].

After six weeks, Poly(I:C) induces in mice clinical and biological signs of MG: 1) Using a grip strength apparatus, which is a global test of fatigability, Poly(I:C)-injected mice were weaker compared to control mice. 2) Poly(I:C) triggers the production of anti-AChR antibodies and B cells purified from lymph nodes proliferate more strongly in the presence of AChR in vitro. 3) AChR density on mouse diaphragm muscle is decreased in Poly(I:C)injected mice, suggesting a partial loss of AChR on diaphragm muscle that could be due to the destruction of AChR by anti-AChR antibodies [38].

Compared to the classical EAMG model, clinical signs are more subtle but all mice are almost similarly affected. The levels of anti-AChR antibodies are lower but they are specifically directed against the mouse AChR and could be more efficient in targeting AChR on mouse muscle. In contrast, in the EAMG model, anti-AChR antibodies are much higher but these antibodies are mainly directed against the $\mathrm{T}-\mathrm{AChR}$ and the titer against mouse AChR range only between 0.2 and $2 \%$ of T-AChR [104].

In Poly(I:C) injected mice, the thymic changes occurring after one week, are not observed anymore after six weeks, but the initial changes associated with the recruitment of B cells could be sufficient to trigger a sensitization against $\alpha$-AChR. These autoreactive B cells could afterwards migrate to the periphery as they do in human MG. Indeed, Fujii et al. demonstrated that autoreactive B cells are found in lymph nodes of MG patients [105]. In Poly(I:C)-injected mice, $\alpha-A C h R$ autoreactive B cells are also present in lymph nodes. Nevertheless, in contrast to the human pathology, no thymic GCs are found even after prolonged injections of Poly(I:C). It is clear that the genetic background involved in human MG is not recapitulated in mice and this could explain their ability to overcome initial thymic changes. 
This study shows that MG symptoms can be induced in mice without active immunization with T-AChR or AChR peptides. Indeed, dsRNA signaling activation reflects a pathogen infection that could induce an autoimmune response against AChR. Poly(I:C) injections on their own have also been shown to favor the development of other experimental autoimmune models in genetically susceptible mouse strain. Poly(I:C) treatment induces local joint inflammation as in arthritis, if administered directly into the joints of healthy mice [106]. It can induce an early development of primary biliary cirrhosis-like cholangitis in C57BL/6 mice [107] and of pancreatitis in MRL/Mp mice [108]. Poly(I:C) aggravates lupus nephritis in MRL lpr/lpr mice [109] [110] and accelerate the development of salivary gland disease in NZB/WF1 mice, a strain susceptible to Sjögren's syndrome disease development [111].

In parallel, Poly(I:C) has also been used to boost the adjuvant effect of CFA or IFA in classical autoimmune experimental models. Simultaneous administration of Poly(I:C) in $\mathrm{BALB} / \mathrm{c}$ mice immunized with an insulin peptide in IFA induces insulitis [112]. Poly(I:C) injections exacerbates the retinal autoimmunity model induced by the immunization of mice with the retinal autoantigen interphotoreceptor retinoid-binding protein (IRBP) in CFA [113]. Poly(I:C) also aggravates the autoimmune cholangitis model induced by 2-octynoic acid injections in CFA [114]. Generally, Poly(I:C) exacerbates the symptoms but it can also suppress relapsing demyelination in a murine experimental autoimmune encephalomyelitis model via the induction of IFN- $\beta$ [115]. This specific improving effect of Poly(I:C) in the encephalomyelitis model is probably related to the fact that in contrast to many other autoimmune diseases, IFN-I plays a neuroprotective role in the central nervous system [116]. Moreover, IFN- $\beta$ is beneficial for multiple sclerosis patients and used as a treatment [117]. Experiments are also going on in our laboratory to investigate the effects of Poly(I:C) injections in the classical EAMG model in an attempt to increase the percentage of mice 
with MG symptoms and develop a MG mouse model with thymic hyperplasia. Preliminary experiments are very encouraging as almost all animals get sick (unpublished data).

\subsection{Improving MG experimental models}

The classical EAMG model obtained with T-ACHR immunization in CFA has been used for more than 40 years in research laboratories to improve the understanding of the human disease and also to test different therapeutic approaches [118] [119] [78]. The rat model is more sensitive to $\mathrm{T}-\mathrm{AChR}$ immunization as one injection is sufficient to trigger MG symptoms. The mouse model is more challenging but is very convenient to test transgenic mice. These models are perfectly relevant to study the consequences of the autoimmune attack of AChR. Unfortunately, mouse or rat models do not present thymic abnormalities as observed in the human disease [120]. Thymectomy of rats with EAMG do not improve either the evolution of the disease [121]. These observations indicate that thymic abnormalities observed in human MG do not result from the production of anti-AChR antibodies in the periphery but rather suggest the role of the thymus as the effector organ in the human pathology.

Abnormal overexpression of CXCL13 is observed in many inflamed tissues, in particular in autoimmune diseases. Thymic hyperplasia observed in EOMG patients is characterized by ectopic GCs and is correlated with high levels of anti-AChR antibodies [6]. The B-cell chemoattractant, CXCL13 is overexpressed by TECs in EOMG patients and suspected to trigger B-cell recruitment in MG [28]. A novel transgenic mouse with a keratin 5 driven CXCL13 expression has been created by Weiss and collaborators. These mice display a clear thymic overexpression of CXCL13 and has been used for the classical EAMG model. These transgenic mice are clearly more susceptible to EAMG and display stronger clinical signs, higher titers of anti-AChR antibodies. Moreover in the thymus a recruitment of B cells is observed and the development of GC-like structures is detected in a few mice. The fact that 
not all mice display thymic GCs could also reflect what is observed in the human disease as not all patients have thymic GCs. Altogether this EAMG model recapitulated better the human pathology than the classical model with C57BL/6 mice which do not show thymic pathology. Moreover, data suggest that thymic follicular hyperplasia is the result of combined features, including overexpression of CXCL13 and increased inflammation due to CFA [40].

This novel transgenic mouse model is of particular interest as it finally mimics the thymic pathology observed in human MG.

\section{Conclusion}

Abnormal TLR signaling activation and uncontrolled resolution of inflammation are suspected to play a key role in the development of autoimmune diseases and possibly in the chronicity of these diseases. Experimental models have been developed for numerous autoimmune diseases. These models almost all rely on animal immunization with an antigen solubilized in CFA (Table 2). It is clear that CFA effects are mainly due to MTB and the activation of TLR signaling pathways. Diverse attempts in research laboratories have been made to try to substitute CFA by the use of TLR agonists, such as LPS and CpG known to activate TLR4 and TLR9, respectively, as MTB does. LPS with IFA have proved to be efficient to induce EAMG and thyroiditis [122] [102]. The results obtained with CpGcontaining oligodeoxynucleotides are more contradictory as TLR9 activation seems to protect animal in experimental autoimmune models, such as diabetes, Sjogren's syndrome and encephalomyelitis models [123] [124] [125].

If dsRNA signalization is not the main mode of action of microbial patterns display by MTB, Poly(I:C) has nevertheless been largely tested and proves to be efficient with or without CFA to induce experimental autoimmune models [106] [107] [108] [109] [110] [111]. 
As the use of CFA is more and more restricted because of painful adverse effects and the restrictions of national regulatory authorities, the development of alternative adjuvants for induced experimental autoimmune models is a necessity for the incoming years. However, the most difficult challenge will be to switch to these new models as the literature on induced models using CFA is rich. These models have been used for years to better understand pathological mechanisms and to test new therapeutic approaches. For experimental models based on the use of TLR agonists, we do not have yet so much hindsight. However, an ideal alternative adjuvant resides probably in the use of a mix of different TLR agonists. 


\section{Acknowledgements}

We thank Profs Remi Nottin and Elie Fadel for the thymic samples, and Vincent de Montpreville for histological analyzes.

We thank the "Agence Nationale de la Recherche" (ANR-06-MRAR-001-01), from the European Community (MYASTAID/LSHM-CT-2006-037833 and FIGHT-MG/HEALTH2009-242-210) and from the "Association Française contre les Myopathies" (AFM).

\section{Conflict of interest}

The authors have declared that no conflict of interest exists. 


\section{Figure legends}

\section{Figure 1: Central role of IFN- $\beta$ in thymic changes associated with MG.}

IFN- $\beta$ induces the expression in thymic epithelial cells (TECs) of $\alpha$-AChR, the main autoantigen in MG. This effect is very specific, as IFN-I do not induce the expression of other AChR subunits or other tissue-specific antigens. IFN- $\beta$ also induces TEC death and the uptake of TEC proteins by dendritic cells, suggesting a potential sensitization of dendritic cells to the $\alpha$-AChR [39]. In parallel, IFN- $\beta$ increases the expression of the chemokines CXCL13 and CCL21 by TECs and lymphatic endothelial cells, respectively [39]. These two chemokines are involved in GC development and are overexpressed in MG with follicular hyperplasia [28] [13]. We also demonstrated that the B-cell activating factor (BAFF), which favors autoreactive B-cells, was overexpressed by TECs in MG thymus and was also induced by IFN- $\beta$ [39].

Altogether, these results demonstrate that IFN- $\beta$ plays a central role in thymic events leading to $\mathrm{MG}$ by triggering the overexpression of $\alpha$-AChR probably leading to thymic $\mathrm{DC}$ autosensitization against $\mathrm{AChR}$, and the abnormal recruitment of peripheral cells involved in germinal center formation.

\section{Figure 2: Analyzis of TLR mRNA expression in the thymus of MG patients.}

Thymic fragments were obtained from MG female patients (15-44 years old) after thymectomy or from adult females (15-30 years old) undergoing cardiovascular surgery at the Marie Lannelongue Chirurgical Center (Le Plessis Robinson, France). MG patients were all anti-AChR positive treated by anti-cholinesterase drugs but had no other known diseases (including thymoma). Thymuses were classified as follows: non-MG adults (Ad, n=6-13), MG patients with low thymic hyperplasia (ML; with 2 or fewer GCs per section, $n=6-13$ ) or 
high thymic hyperplasia (MH; with 3 or more GCs per section, n=6-13), or corticosteroidtreated MG patients (Cortico, $\mathrm{n}=6-11$ ). All the studies on thymuses were approved by the local Ethics Committee (CCP agreement $\mathrm{N}^{\circ} \mathrm{C} 09-36$ - France).

Total RNA was extracted, reverse-transcribed and analyzed by real-time PCR on the LightCycler 480 system as previously described [39]. The primer used were as follows:

TLRI (F: 5'GGGTCAGCTGGACTTCAGAG 3', R: 5' AAAATCCAAATGGAGGAACG 3'), TLR2 (F: 5'GGGTTGAAGCACTGGACAAT 3' , R: 5'TCCTGTTGTTGGACAGGTCA $\quad 3$ '), TLR3 (F : 5'AGCCTTCAACGACTGATGCT $\quad$ 3', R: $\quad$ 5'TTTCCAGAGCGGTGCTAAGT $\quad$ 3'), TLR4 (F: 5'TGaGCAGTCGTGCTGGTAtC 3', R: $\quad$ 5'CAGGGCTTtTCTGAGTCGTC 3'), TLR5 (F:

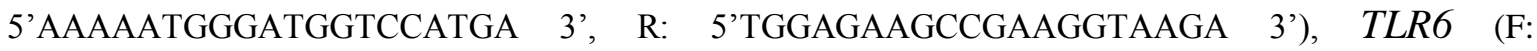
5'TAAATTGGACTGGCCTGGAC $\quad$ 3'， R: $\quad$ 5'GGCCGAAACTGGTTTATTGA $\quad$ 3'), TLR7 (F: 5'CCTTGAGGCCAACAACATCT $\quad$ 3', R: $\quad$ 5'GTAGGGACGGCTGTGACATT $\quad$ 3'), TLR8 (F: 5'CAGAGCATCAACCAAAGCAA $\quad$ 3', R: 5'CTGTAACACTGGCTCCCAGCA 3 '), TLR9 (F: 5'CAGCAGCTCTGCAGTACGTC 3', R: 5'AAGGCCAGGTAATTGTCACG 3'), CD19 (F: 5'TACTATGGCACTGGCTGCTG $\quad$ 3'， R: $\quad$ 5'CACGTTCCCGTACTGGTTCT $\quad 3{ }^{\prime}$ ), $28 S$ (F: 5' GGTAGGGACAGTGGGAATCT 3', R: 5'CGGGTAAACGGCGGGAGTAA 3').

(A) mRNA expression level for TLRs in the thymus. mRNA expression was normalized to 28S RNA. p-values were assessed by the Mann-Whitney test and p-values $<0.05$ are indicated. (B) Correlations of CD19 mRNA expression and TLR mRNA expression in all thymic samples. The p-values were obtained by the nonparametric correlation test (Spearman test). 
Table 1: List of human TLRs.

\begin{tabular}{|c|c|c|c|c|c|}
\hline TLRs & Ligands & $\begin{array}{c}\text { Cellular } \\
\text { localization }\end{array}$ & $\begin{array}{l}\text { Interaction } \\
\text { with other } \\
\text { TLRs }\end{array}$ & $\begin{array}{l}\text { First adaptor } \\
\text { for } \\
\text { signalization }\end{array}$ & References \\
\hline TLR1 & Triacyl lipoproteins from bacteria & Cell surface & $\begin{array}{l}\text { TLR2 } \\
\text { TLR4 }\end{array}$ & MyD88 & {$[126]$} \\
\hline TLR2 & $\begin{array}{l}\text { Microbial molecules from bacteria } \\
\text { Mycoplasma and yeast }\end{array}$ & Cell surface & $\begin{array}{c}\text { TLR1 } \\
\text { TLR6 } \\
\text { TLR10 }\end{array}$ & $\begin{array}{l}\text { MyD88 } \\
\text { TRIF }\end{array}$ & {$[127][55]$} \\
\hline TLR3 & dsRNA from viruses & $\begin{array}{l}\text { Endosomes } \\
\text { Cell surface }\end{array}$ & & TRIF & $\begin{array}{l}{[128][57]} \\
{[129]}\end{array}$ \\
\hline TLR4 & $\begin{array}{l}\text { Lipopolysaccharide from Gram-negative } \\
\text { bacteria } \\
\text { Mannans from yeast } \\
\text { Glycoinositolphospholipids from the } \\
\text { protozoan Trypanosoma cruzi } \\
\text { Respiratory syncytial virus fusion protein }\end{array}$ & Cell surface & $\begin{array}{l}\text { TLR1 } \\
\text { TLR5 }\end{array}$ & $\begin{array}{l}\text { MyD88 } \\
\text { TRIF }\end{array}$ & [98] [130] \\
\hline TLR5 & Flagellin from bacteria & Cell surface & TLR4 & $\begin{array}{l}\text { MyD88 } \\
\text { TRIF }\end{array}$ & {$[131][53]$} \\
\hline TLR6 & $\begin{array}{l}\text { Diacyl lipoproteins from bacteria } \\
\text { Mycoplasma }\end{array}$ & Cell surface & TLR2 & MyD88 & [126] \\
\hline TLR7 & ssRNA from viruses & Endosomes & & MyD88 & {$[128][58]$} \\
\hline TLR8 & ssRNA from viruses & Endosomes & & MyD88 & [59] [132] \\
\hline TLR9 & $\begin{array}{l}\text { Unmethylated CpG oligonucleotide DNA } \\
\text { from viruses and bacteria }\end{array}$ & $\begin{array}{l}\text { Endosomes } \\
\text { Cell surface }\end{array}$ & & $\begin{array}{l}\text { MyD88 } \\
\text { TRIF }\end{array}$ & $\begin{array}{l}{[133][54]} \\
{[60]}\end{array}$ \\
\hline TLR10 & $\begin{array}{l}\text { Functional RNA-protein complex of } \\
\text { influenza virus }\end{array}$ & Cell surface & TLR2 & MyD88 & {$[134][135]$} \\
\hline TLR11 & $\begin{array}{l}\text { Flagellin from bacteria } \\
\text { Profilin-like molecule from Toxoplasma } \\
\text { gondii }\end{array}$ & Endosomes & & MyD88 & {$[136]$} \\
\hline
\end{tabular}


Table 2: Experimental mouse models for autoimmune diseases using CFA to induce an active immunization against a specific antigen.

\begin{tabular}{|c|c|c|c|c|}
\hline $\begin{array}{c}\text { Autoimmune } \\
\text { disease }\end{array}$ & $\begin{array}{c}\text { Induced experimental } \\
\text { mouse model }\end{array}$ & $\begin{array}{c}\text { Antigen used } \\
\text { for immunization }\end{array}$ & $\begin{array}{c}\text { Main } \\
\text { adjuvant }\end{array}$ & References \\
\hline Rheumatoid arthritis & $\begin{array}{l}\text { Collagen-induced arthritis } \\
\text { (CIA) }\end{array}$ & Collagen II & CFA & [137] \\
\hline Multiple sclerosis & $\begin{array}{l}\text { Experimental autoimmune } \\
\text { encephalomyelitis (EAE) }\end{array}$ & $\begin{array}{l}\text { Proteolipid protein (PLP), } \\
\text { Myelin basic protein (MBP) } \\
\text { Myelin oligodendrocyte } \\
\text { glycoprotein (MOG) }\end{array}$ & CFA & {$[138]$} \\
\hline Myasthenia Gravis & $\begin{array}{l}\text { Experimental autoimmune } \\
\text { myasthenia gravis (EAMG) }\end{array}$ & $\begin{array}{c}\text { Acetylcholine receptor } \\
\text { (AChR) }\end{array}$ & CFA & [78] \\
\hline Myositis & $\begin{array}{l}\text { Experimental autoimmune } \\
\text { myositis (EAM) }\end{array}$ & Myosin & CFA & [139] \\
\hline $\begin{array}{c}\text { Autoimmune } \\
\text { inflammatory heart } \\
\text { disease }\end{array}$ & $\begin{array}{l}\text { Experimental autoimmune } \\
\text { myocarditis (EAM) }\end{array}$ & $\begin{array}{l}\alpha \text {-myosin heavy chain } \\
\text { peptide }\end{array}$ & CFA & [89] \\
\hline $\begin{array}{c}\text { Autoimmune } \\
\text { hepatitis }\end{array}$ & $\begin{array}{c}\text { Experimental autoimmune } \\
\text { hepatitis (EAH) }\end{array}$ & Syngeneic S-100 antigen & CFA & [140] \\
\hline Autoimmune uveitis & $\begin{array}{c}\text { Experimental autoimmune } \\
\text { uveitis (EAU) }\end{array}$ & $\begin{array}{l}\text { Interphotoreceptor retinoid- } \\
\text { binding protein (IRBP) }\end{array}$ & CFA & [91] \\
\hline $\begin{array}{l}\text { Primary biliary } \\
\text { cholangitis }\end{array}$ & $\begin{array}{l}\text { Murine autoimmune } \\
\text { cholangitis (EAC) }\end{array}$ & 2-octynoic acid (2-OA) & CFA & {$[141]$} \\
\hline $\begin{array}{l}\text { Glomerulonephritis } \\
\text { and vasculitis }\end{array}$ & $\begin{array}{l}\text { Experimental autoimmune } \\
\text { vasculitis (EAV) }\end{array}$ & Myeloperoxidase (MPO) & CFA & [142] \\
\hline $\begin{array}{l}\text { The antiphospholipid } \\
\text { syndrome }\end{array}$ & $\begin{array}{c}\text { Experimental } \\
\text { antiphospholipid syndrome } \\
\text { (EAPS) }\end{array}$ & $\beta 2$-glycoprotein I ( $\beta 2$-GPI) & CFA & [143] \\
\hline $\begin{array}{l}\text { Hashimoto's } \\
\text { Thyroiditis }\end{array}$ & $\begin{array}{l}\text { Experimental autoimmune } \\
\text { thyroiditis (EAT) }\end{array}$ & Thyroglobulin (Tg) & CFA & {$[102]$} \\
\hline
\end{tabular}




\section{References}

1. Berrih-Aknin S, Le Panse R (2014) Myasthenia gravis: A comprehensive review of immune dysregulation and etiological mechanisms. J Autoimmun 52: 90-100.

2. Hoch W, McConville J, Helms S, Newsom-Davis J, Melms A, et al. (2001) Autoantibodies to the receptor tyrosine kinase MuSK in patients with myasthenia gravis without acetylcholine receptor antibodies. Nature Medicine 7: 365-368.

3. Higuchi O, Hamuro J, Motomura M, Yamanashi Y (2011) Autoantibodies to low-density lipoprotein receptor-related protein 4 in myasthenia gravis. Annals of Neurology 69: 418-422.

4. Zhang B, Shen C, Bealmear B, Ragheb S, Xiong WC, et al. (2014) Autoantibodies to agrin in myasthenia gravis patients. PLoS One 9: e91816.

5. Nicolle MW (2002) Myasthenia gravis. Neurologist 8: 2-21.

6. Berrih-Aknin S, Morel E, Raimond F, Safar D, Gaud C, et al. (1987) The role of the thymus in myasthenia gravis: immunohistological and immunological studies in 115 cases. Annals of the New York Academy of Sciences 505: 50-70.

7. Levinson AI, Wheatley LM (1996) The thymus and the pathogenesis of myasthenia gravis. Clin Immunol Immunopathol 78: 1-5.

8. Evoli A, Tonali PA, Padua L, Monaco ML, Scuderi F, et al. (2003) Clinical correlates with anti-MuSK antibodies in generalized seronegative myasthenia gravis. Brain 126: 2304-2311.

9. Ponseti JM, Caritg N, Gamez J, Lopez-Cano M, Vilallonga R, et al. (2009) A comparison of long-term post-thymectomy outcome of anti-AChR-positive, anti-AChR-negative and anti-MuSK-positive patients with non-thymomatous myasthenia gravis. Expert Opin Biol Ther 9: 1-8. 
10. Anderson G, Takahama Y (2012) Thymic epithelial cells: working class heroes for T cell development and repertoire selection. Trends Immunol 33: 256-263.

11. Suniara RK, Jenkinson EJ, Owen JJ (2000) An essential role for thymic mesenchyme in early T cell development. Journal of Experimental Medecine 191: 1051-1056.

12. Derbinski J, Gabler J, Brors B, Tierling S, Jonnakuty S, et al. (2005) Promiscuous gene expression in thymic epithelial cells is regulated at multiple levels. J Exp Med 202: 33 45.

13. Berrih-Aknin S, Ruhlmann N, Bismuth J, Cizeron-Clairac G, Zelman E, et al. (2009) CCL21 overexpressed on lymphatic vessels drives thymic hyperplasia in myasthenia. Ann Neurol 66: 521-531.

14. Le Panse R, Bismuth J, Cizeron-Clairac G, Weiss JM, Cufi P, et al. (2010) Thymic remodeling associated with hyperplasia in myasthenia gravis. Autoimmunity 43: 1-12.

15. Weiss JM, Cufi P, Bismuth J, Eymard B, Fadel E, et al. (2013) SDF-1/CXCL12 recruits B cells and antigen-presenting cells to the thymus of autoimmune myasthenia gravis patients. Immunobiology 218: 373-381.

16. Weiss JM, Cufi P, Le Panse R, Berrih-Aknin S (2013) The thymus in autoimmune Myasthenia Gravis: Paradigm for a tertiary lymphoid organ. Rev Neurol (Paris) 169: 640-649.

17. Ruddle NH (2014) Lymphatic vessels and tertiary lymphoid organs. J Clin Invest 124: 953-959.

18. Wakkach A, Guyon T, Bruand C, Tzartos S, Cohen-Kaminsky S, et al. (1996) Expression of acetylcholine receptor genes in human thymic epithelial cells: implications for myasthenia gravis. J Immunol 157: 3752-3760. 
19. Safar D, Berrih-Aknin S, Morel E (1987) In vitro anti-acetylcholine receptor antibody synthesis by myasthenia gravis patient lymphocytes: correlations with thymic histology and thymic epithelial-cell interactions. J Clin Immunol 7: 225-234.

20. Leprince C, Cohen-Kaminsky S, Berrih-Aknin S, Vernet-Der Garabedian B, Treton D, et al. (1990) Thymic B cells from myasthenia gravis patients are activated B cells. Phenotypic and functional analysis. J Immunol 145: 2115-2122.

21. Melms A, Schalke BC, Kirchner T, Muller-Hermelink HK, Albert E, et al. (1988) Thymus in myasthenia gravis. Isolation of T-lymphocyte lines specific for the nicotinic acetylcholine receptor from thymuses of myasthenic patients. J Clin Invest 81: 902-908.

22. Kuks JB, Oosterhuis HJ, Limburg PC, The TH (1991) Anti-acetylcholine receptor antibodies decrease after thymectomy in patients with myasthenia gravis. Clinical correlations. Journal of Autoimmunity 4: 197-211.

23. Papatestas AE, Alpert LI, Osserman KE, Osserman RS, Kark AE (1971) Studies in myasthenia gravis: effects of thymectomy. Results on 185 patients with nonthymomatous and thymomatous myasthenia gravis, 1941-1969. Am J Med 50: 465474.

24. Feferman T, Maiti PK, Berrih-Aknin S, Bismuth J, Bidault J, et al. (2005) Overexpression of IFN-induced protein 10 and its receptor CXCR3 in myasthenia gravis. J Immunol 174: 5324-5331.

25. Cordiglieri C, Marolda R, Franzi S, Cappelletti C, Giardina C, et al. (2014) Innate immunity in myasthenia gravis thymus: pathogenic effects of Toll-like receptor 4 signaling on autoimmunity. J Autoimmun 52: 74-89.

26. Legler DF, Loetscher M, Roos RS, Clark-Lewis I, Baggiolini M, et al. (1998) B cellattracting chemokine 1, a human CXC chemokine expressed in lymphoid tissues, selectively attracts B lymphocytes via BLR1/CXCR5. J Exp Med 187: 655-660. 
27. Barone F, Bombardieri M, Manzo A, Blades MC, Morgan PR, et al. (2005) Association of CXCL13 and CCL21 expression with the progressive organization of lymphoid-like structures in Sjogren's syndrome. Arthritis Rheum 52: 1773-1784.

28. Méraouna A, Cizeron-Clairac G, Le Panse R, Bismuth J, Truffault F, et al. (2006) The chemokine CXCL13 is a key molecule in autoimmune Myasthenia Gravis. Blood 108: 432-440.

29. Le Panse R, Cizeron-Clairac G, Bismuth J, Berrih-Aknin S (2006) Microarrays reveal distinct gene signatures in the thymus of seropositive and seronegative myasthenia gravis patients and the role of CC chemokine ligand 21 in thymic hyperplasia. $\mathrm{J}$ Immunol 177: 7868-7879.

30. Shiao YM, Lee CC, Hsu YH, Huang SF, Lin CY, et al. (2010) Ectopic and high CXCL13 chemokine expression in myasthenia gravis with thymic lymphoid hyperplasia. $\mathbf{J}$ Neuroimmunol 221: 101-106.

31. Zhang M, Guo J, Li H, Zhou Y, Tian F, et al. (2013) Expression of immune molecules CD25 and CXCL13 correlated with clinical severity of myasthenia gravis. J Mol Neurosci 50: 317-323.

32. Stubgen JP (2009) Interferon alpha and neuromuscular disorders. J Neuroimmunol 207: $3-17$.

33. Meager A, Wadhwa M, Dilger P, Bird C, Thorpe R, et al. (2003) Anti-cytokine autoantibodies in autoimmunity: preponderance of neutralizing autoantibodies against interferon-alpha, interferon-omega and interleukin-12 in patients with thymoma and/or myasthenia gravis. Clin Exp Immunol 132: 128-136.

34. Meloni A, Furcas M, Cetani F, Marcocci C, Falorni A, et al. (2008) Autoantibodies against type I interferons as an additional diagnostic criterion for autoimmune polyendocrine syndrome type I. J Clin Endocrinol Metab 93: 4389-4397. 
35. Poea-Guyon S, Christadoss P, Le Panse R, Guyon T, De Baets M, et al. (2005) Effects of cytokines on acetylcholine receptor expression: implications for myasthenia gravis. J Immunol 174: 5941-5949.

36. Le Panse R, Cizeron-Clairac G, Cuvelier M, Truffault F, Bismuth J, et al. (2008) Regulatory and pathogenic mechanisms in human autoimmune myasthenia gravis. Ann N Y Acad Sci 1132: 135-142.

37. Golding A, Rosen A, Petri M, Akhter E, Andrade F (2010) Interferon-alpha regulates the dynamic balance between human activated regulatory and effector $\mathrm{T}$ cells: implications for antiviral and autoimmune responses. Immunology 131: 107-117.

38. Cufi P, Dragin N, Weiss JM, Martinez-Martinez P, De Baets MH, et al. (2013) Implication of double-stranded RNA signaling in the etiology of autoimmune myasthenia gravis. Ann Neurol 73: 281-293.

39. Cufi P, Dragin N, Ruhlmann N, Weiss JM, Fadel E, et al. (2014) Central role of interferon-beta in thymic events leading to myasthenia gravis. J Autoimmun 52: 44-52.

40. Weiss JM, Robinet M, Aricha R, Cufi P, Villeret B, et al. (2016) Novel CXCL13 transgenic mouse: inflammation drives pathogenic effect of CXCL13 in experimental myasthenia gravis. Oncotarget.

41. Cufi P, Soussan P, Truffault F, Fetouchi R, Robinet M, et al. (2014) Thymoma-associated myasthenia gravis: On the search for a pathogen signature. J Autoimmun 52: 29-35.

42. Okada H, Kuhn C, Feillet H, Bach JF (2010) The 'hygiene hypothesis' for autoimmune and allergic diseases: an update. Clin Exp Immunol 160: 1-9.

43. Munz C, Lunemann JD, Getts MT, Miller SD (2009) Antiviral immune responses: triggers of or triggered by autoimmunity? Nature Reviews: Immunology 9: 246-258.

44. Savino W (2006) The thymus is a common target organ in infectious diseases. PLoS Pathogens 2: e62. 
45. Cavalcante P, Barberis M, Cannone M, Baggi F, Antozzi C, et al. (2010) Detection of poliovirus-infected macrophages in thymus of patients with myasthenia gravis. Neurology 74: 1118-1126.

46. Cavalcante P, Serafini B, Rosicarelli B, Maggi L, Barberis M, et al. (2010) Epstein-Barr virus persistence and reactivation in myasthenia gravis thymus. Annals of Neurology 67: 726-738.

47. Niller HH, Wolf H, Ay E, Minarovits J (2011) Epigenetic dysregulation of epstein-barr virus latency and development of autoimmune disease. Adv Exp Med Biol 711: 82-102.

48. Ning S (2011) Innate immune modulation in EBV infection. Herpesviridae 2: 1.

49. Kawai T, Akira S (2010) The role of pattern-recognition receptors in innate immunity: update on Toll-like receptors. Nature Immunology 11: 373-384.

50. Kawasaki T, Kawai T (2014) Toll-like receptor signaling pathways. Front Immunol 5: 461.

51. Mohammad Hosseini A, Majidi J, Baradaran B, Yousefi M (2015) Toll-Like Receptors in the Pathogenesis of Autoimmune Diseases. Adv Pharm Bull 5: 605-614.

52. Chen JQ, Szodoray P, Zeher M (2016) Toll-Like Receptor Pathways in Autoimmune Diseases. Clin Rev Allergy Immunol 50: 1-17.

53. Choi YJ, Im E, Chung HK, Pothoulakis C, Rhee SH (2010) TRIF mediates Toll-like receptor 5-induced signaling in intestinal epithelial cells. J Biol Chem 285: 3757037578 .

54. Volpi C, Fallarino F, Pallotta MT, Bianchi R, Vacca C, et al. (2013) High doses of CpG oligodeoxynucleotides stimulate a tolerogenic TLR9-TRIF pathway. Nat Commun 4: 1852. 
55. Nilsen NJ, Vladimer GI, Stenvik J, Orning MP, Zeid-Kilani MV, et al. (2015) A role for the adaptor proteins TRAM and TRIF in toll-like receptor 2 signaling. J Biol Chem 290: 3209-3222.

56. Perkins DJ, Vogel SN (2015) Space and time: New considerations about the relationship between Toll-like receptors (TLRs) and type I interferons (IFNs). Cytokine 74: 171174.

57. Pohar J, Pirher N, Bencina M, Mancek-Keber M, Jerala R (2013) The role of UNC93B1 protein in surface localization of TLR3 receptor and in cell priming to nucleic acid agonists. J Biol Chem 288: 442-454.

58. Kanno A, Tanimura N, Ishizaki M, Ohko K, Motoi Y, et al. (2015) Targeting cell surface TLR7 for therapeutic intervention in autoimmune diseases. Nat Commun 6: 6119.

59. Itoh H, Tatematsu M, Watanabe A, Iwano K, Funami K, et al. (2011) UNC93B1 physically associates with human TLR8 and regulates TLR8-mediated signaling. PLoS One 6: e28500.

60. Guerrier T, Pochard P, Lahiri A, Youinou P, Pers JO, et al. (2014) TLR9 expressed on plasma membrane acts as a negative regulator of human B cell response. J Autoimmun 51: 23-29.

61. Hurst J, von Landenberg P (2008) Toll-like receptors and autoimmunity. Autoimmun Rev 7: 204-208.

62. Duthie MS, Windish HP, Fox CB, Reed SG (2011) Use of defined TLR ligands as adjuvants within human vaccines. Immunol Rev 239: 178-196.

63. Jin B, Sun T, Yu XH, Yang YX, Yeo AE (2012) The effects of TLR activation on T-cell development and differentiation. Clin Dev Immunol 2012: 836485.

64. Crampton SP, Voynova E, Bolland S (2010) Innate pathways to B-cell activation and tolerance. Ann N Y Acad Sci 1183: 58-68. 
65. Green NM, Moody KS, Debatis M, Marshak-Rothstein A (2012) Activation of autoreactive B cells by endogenous TLR7 and TLR3 RNA ligands. J Biol Chem.

66. Meyer-Bahlburg A, Rawlings DJ (2008) B cell autonomous TLR signaling and autoimmunity. Autoimmun Rev 7: 313-316.

67. Green NM, Marshak-Rothstein A (2011) Toll-like receptor driven B cell activation in the induction of systemic autoimmunity. Semin Immunol 23: 106-112.

68. Wang YZ, Yan M, Tian FF, Zhang JM, Liu Q, et al. (2013) Possible involvement of tolllike receptors in the pathogenesis of myasthenia gravis. Inflammation 36: 121-130.

69. Lu J, Yan M, Wang Y, Zhang J, Yang H, et al. (2013) Altered expression of miR-146a in myasthenia gravis. Neurosci Lett 555: 85-90.

70. Zarember KA, Godowski PJ (2002) Tissue expression of human Toll-like receptors and differential regulation of Toll-like receptor mRNAs in leukocytes in response to microbes, their products, and cytokines. J Immunol 168: 554-561.

71. Bernasconi P, Barberis M, Baggi F, Passerini L, Cannone M, et al. (2005) Increased tolllike receptor 4 expression in thymus of myasthenic patients with thymitis and thymic involution. Am J Pathol 167: 129-139.

72. Cavalcante P, Galbardi B, Franzi S, Marcuzzo S, Barzago C, et al. (2016) Increased expression of Toll-like receptors 7 and 9 in myasthenia gravis thymus characterized by active Epstein-Barr virus infection. Immunobiology 221: 516-527.

73. Quan TE, Roman RM, Rudenga BJ, Holers VM, Craft JE (2010) Epstein-Barr virus promotes interferon-alpha production by plasmacytoid dendritic cells. Arthritis Rheum 62: 1693-1701.

74. Iwakiri D, Zhou L, Samanta M, Matsumoto M, Ebihara T, et al. (2009) Epstein-Barr virus (EBV)-encoded small RNA is released from EBV-infected cells and activates signaling from Toll-like receptor 3. J Exp Med 206: 2091-2099. 
75. Gaudreault E, Fiola S, Olivier M, Gosselin J (2007) Epstein-Barr virus induces MCP-1 secretion by human monocytes via TLR2. J Virol 81: 8016-8024.

76. Valente RM, Ehlers E, Xu D, Ahmad H, Steadman A, et al. (2012) Toll-like receptor 7 stimulates the expression of Epstein-Barr virus latent membrane protein 1. PLoS One 7: e43317.

77. Fuchs S, Aricha R, Reuveni D, Souroujon MC (2014) Experimental Autoimmune Myasthenia Gravis (EAMG): from immunochemical characterization to therapeutic approaches. J Autoimmun 54: 51-59.

78. Tuzun E, Berrih-Aknin S, Brenner T, Kusner LL, Le Panse R, et al. (2015) Guidelines for standard preclinical experiments in the mouse model of myasthenia gravis induced by acetylcholine receptor immunization. Exp Neurol.

79. Wu B, Goluszko E, Huda R, Tuzun E, Christadoss P (2013) Experimental autoimmune myasthenia gravis in the mouse. Curr Protoc Immunol Chapter 15: Unit 1518.

80. Losen M, Martinez-Martinez P, Molenaar PC, Lazaridis K, Tzartos S, et al. (2015) Standardization of the experimental autoimmune myasthenia gravis (EAMG) model by immunization of rats with Torpedo californica acetylcholine receptors-Recommendations for methods and experimental designs. Exp Neurol 270: 18-28.

81. Billiau A, Matthys P (2001) Modes of action of Freund's adjuvants in experimental models of autoimmune diseases. J Leukoc Biol 70: 849-860.

82. Milani M, Ostlie N, Wu H, Wang W, Conti-Fine BM (2006) CD4+ T and B cells cooperate in the immunoregulation of Experimental Autoimmune Myasthenia Gravis. J Neuroimmunol 179: 152-162.

83. Shibaki A, Katz SI (2002) Induction of skewed Th1/Th2 T-cell differentiation via subcutaneous immunization with Freund's adjuvant. Exp Dermatol 11: 126-134. 
84. Balasa B, Deng C, Lee J, Bradley LM, Dalton DK, et al. (1997) Interferon gamma (IFNgamma) is necessary for the genesis of acetylcholine receptor-induced clinical experimental autoimmune myasthenia gravis in mice. J Exp Med 186: 385-391.

85. Zhang GX, Xiao BG, Bai XF, van der Meide PH, Orn A, et al. (1999) Mice with IFNgamma receptor deficiency are less susceptible to experimental autoimmune myasthenia gravis. J Immunol 162: 3775-3781.

86. Schaffert H, Pelz A, Saxena A, Losen M, Meisel A, et al. (2015) IL-17-producing CD4(+) T cells contribute to the loss of B-cell tolerance in experimental autoimmune myasthenia gravis. Eur J Immunol 45: 1339-1347.

87. Gavin AL, Hoebe K, Duong B, Ota T, Martin C, et al. (2006) Adjuvant-enhanced antibody responses in the absence of toll-like receptor signaling. Science 314: 19361938.

88. Su SB, Silver PB, Grajewski RS, Agarwal RK, Tang J, et al. (2005) Essential role of the MyD88 pathway, but nonessential roles of TLRs 2, 4, and 9, in the adjuvant effect promoting Th1-mediated autoimmunity. J Immunol 175: 6303-6310.

89. Marty RR, Dirnhofer S, Mauermann N, Schweikert S, Akira S, et al. (2006) MyD88 signaling controls autoimmune myocarditis induction. Circulation 113: 258-265.

90. Sadanaga A, Nakashima H, Akahoshi M, Masutani K, Miyake K, et al. (2007) Protection against autoimmune nephritis in MyD88-deficient MRL/lpr mice. Arthritis Rheum 56: $1618-1628$.

91. Fang J, Fang D, Silver PB, Wen F, Li B, et al. (2010) The role of TLR2, TRL3, TRL4, and TRL9 signaling in the pathogenesis of autoimmune disease in a retinal autoimmunity model. Invest Ophthalmol Vis Sci 51: 3092-3099. 
92. Scadding GK, Calder L, Vincent A, Prior C, Wray D, et al. (1986) Anti-acetylcholine receptor antibodies induced in mice by syngeneic receptor without adjuvants. Immunology 58: 151-155.

93. Jermy A, Beeson D, Vincent A (1993) Pathogenic autoimmunity to affinity-purified mouse acetylcholine receptor induced without adjuvant in BALB/c mice. Eur J Immunol 23: 973-976.

94. Kool M, Soullie T, van Nimwegen M, Willart MA, Muskens F, et al. (2008) Alum adjuvant boosts adaptive immunity by inducing uric acid and activating inflammatory dendritic cells. J Exp Med 205: 869-882.

95. Oshima M, Maruta T, Ohtani M, Deitiker PR, Mosier D, et al. (2006) Vaccination with a MHC class II peptide in Alum and inactive pertussis strongly ameliorates clinical MG in C57BL/6 mice. J Neuroimmunol 171: 8-16.

96. Bennett B, Check IJ, Olsen MR, Hunter RL (1992) A comparison of commercially available adjuvants for use in research. J Immunol Methods 153: 31-40.

97. Shenoy M, Christadoss P (1993) Induction of experimental autoimmune myasthenia gravis with acetylcholine receptors using a nonionic block copolymer as adjuvant. Immunol Invest 22: 267-282.

98. Lu YC, Yeh WC, Ohashi PS (2008) LPS/TLR4 signal transduction pathway. Cytokine 42: $145-151$.

99. Demon D, Vande Walle L, Lamkanfi M (2014) Sensing the enemy within: how macrophages detect intracellular Gram-negative bacteria. Trends Biochem Sci 39: 574576.

100. Liu Y, Yin H, Zhao M, Lu Q (2014) TLR2 and TLR4 in autoimmune diseases: a comprehensive review. Clin Rev Allergy Immunol 47: 136-147. 
101. Rose NR (2008) The adjuvant effect in infection and autoimmunity. Clin Rev Allergy Immunol 34: 279-282.

102. Damotte D, Goulvestre C, Charreire J, Carnaud C (2003) LPS and Freund's adjuvant initiate different inflammatory circuits in experimental autoimmune thyroiditis. Eur Cytokine Netw 14: 52-59.

103. Deane JA, Bolland S (2006) Nucleic acid-sensing TLRs as modifiers of autoimmunity. J Immunol 177: 6573-6578.

104. Berman PW, Patrick J (1980) Experimental myasthenia gravis. A murine system. J Exp Med 151: 204-223.

105. Fujii Y, Monden Y, Hashimoto J, Nakahara K, Kawashima Y (1985) Acetylcholine receptor antibody-producing cells in thymus and lymph nodes in myasthenia gravis. Clin Immunol Immunopathol 34: 141-146.

106. Zare F, Bokarewa M, Nenonen N, Bergstrom T, Alexopoulou L, et al. (2004) Arthritogenic properties of double-stranded (viral) RNA. J Immunol 172: 5656-5663.

107. Okada C, Akbar SM, Horiike N, Onji M (2005) Early development of primary biliary cirrhosis in female C57BL/6 mice because of poly I:C administration. Liver Int 25: 595603.

108. Asada M, Nishio A, Akamatsu T, Tanaka J, Saga K, et al. (2010) Analysis of humoral immune response in experimental autoimmune pancreatitis in mice. Pancreas 39: 224231.

109. Patole PS, Grone HJ, Segerer S, Ciubar R, Belemezova E, et al. (2005) Viral doublestranded RNA aggravates lupus nephritis through Toll-like receptor 3 on glomerular mesangial cells and antigen-presenting cells. J Am Soc Nephrol 16: 1326-1338. 
110. Jorgensen TN, Thurman J, Izui S, Falta MT, Metzger TE, et al. (2006) Genetic susceptibility to polyI:C-induced IFNalpha/beta-dependent accelerated disease in lupusprone mice. Genes Immun 7: 555-567.

111. Nandula SR, Scindia YM, Dey P, Bagavant H, Deshmukh US (2011) Activation of innate immunity accelerates sialoadenitis in a mouse model for Sjogren's syndrome-like disease. Oral Dis 17: 801-807.

112. Moriyama H, Wen L, Abiru N, Liu E, Yu L, et al. (2002) Induction and acceleration of insulitis/diabetes in mice with a viral mimic (polyinosinic-polycytidylic acid) and an insulin self-peptide. Proc Natl Acad Sci U S A 99: 5539-5544.

113. Ren X, Zhou H, Li B, Su SB (2011) Toll-like receptor 3 ligand polyinosinic:polycytidylic acid enhances autoimmune disease in a retinal autoimmunity model. Int Immunopharmacol 11: 769-773.

114. Ambrosini YM, Yang GX, Zhang W, Tsuda M, Shu S, et al. (2011) The multi-hit hypothesis of primary biliary cirrhosis: polyinosinic-polycytidylic acid (poly I:C) and murine autoimmune cholangitis. Clin Exp Immunol 166: 110-120.

115. Touil T, Fitzgerald D, Zhang GX, Rostami A, Gran B (2006) Cutting Edge: TLR3 stimulation suppresses experimental autoimmune encephalomyelitis by inducing endogenous IFN-beta. J Immunol 177: 7505-7509.

116. Khorooshi R, Morch MT, Holm TH, Berg CT, Dieu RT, et al. (2015) Induction of endogenous Type I interferon within the central nervous system plays a protective role in experimental autoimmune encephalomyelitis. Acta Neuropathol 130: 107-118.

117. Jankovic SM (2010) Injectable interferon beta-1b for the treatment of relapsing forms of multiple sclerosis. J Inflamm Res 3: 25-31. 
118. Lennon VA, Lindstrom JM, Seybold ME (1975) Experimental autoimmune myasthenia: A model of myasthenia gravis in rats and guinea pigs. J Exp Med 141: $1365-1375$.

119. Fuchs S, Nevo D, Tarrab-Hazdai R, Yaar I (1976) Strain differences in the autoimmune response of mice to acetylcholine receptors. Nature 263: 329-330.

120. Meinl E, Klinkert WE, Wekerle H (1991) The thymus in myasthenia gravis. Changes typical for the human disease are absent in experimental autoimmune myasthenia gravis of the Lewis rat. Am J Pathol 139: 995-1008.

121. Lennon VA, Lindstrom JM, Seybold ME (1976) Experimental autoimmune myasthenia gravis: cellular and humoral immune responses. Ann N Y Acad Sci 274: 283-299.

122. Allman W, Qi H, Saini SS, Li J, Tuzun E, et al. (2012) CD4 costimulation is not required in a novel LPS-enhanced model of myasthenia gravis. J Neuroimmunol 249: $1-7$.

123. Fallarino F, Volpi C, Zelante T, Vacca C, Calvitti M, et al. (2009) IDO mediates TLR9driven protection from experimental autoimmune diabetes. J Immunol 183: 6303-6312.

124. Gilboa-Geffen A, Wolf Y, Hanin G, Melamed-Book N, Pick M, et al. (2011) Activation of the alternative NFkappaB pathway improves disease symptoms in a model of Sjogren's syndrome. PLoS One 6: e28727.

125. Longhini AL, Santos MP, Pradella F, Moraes AS, Dionete AC, et al. (2014) In vivo administration of TLR9 agonist reduces the severity of experimental autoimmune encephalomyelitis. The role of plasmacytoid dendritic cells and B lymphocytes. CNS Neurosci Ther 20: 787-790.

126. Farhat K, Riekenberg S, Heine H, Debarry J, Lang R, et al. (2008) Heterodimerization of TLR2 with TLR1 or TLR6 expands the ligand spectrum but does not lead to differential signaling. J Leukoc Biol 83: 692-701. 
127. van Bergenhenegouwen J, Plantinga TS, Joosten LA, Netea MG, Folkerts G, et al. (2013) TLR2 \& Co: a critical analysis of the complex interactions between TLR2 and coreceptors. J Leukoc Biol 94: 885-902.

128. Nishiya T, Kajita E, Miwa S, Defranco AL (2005) TLR3 and TLR7 are targeted to the same intracellular compartments by distinct regulatory elements. J Biol Chem 280: $37107-37117$

129. Tatematsu M, Seya T, Matsumoto M (2014) Beyond dsRNA: Toll-like receptor 3 signalling in RNA-induced immune responses. Biochem J 458: 195-201.

130. Liaunardy-Jopeace A, Gay NJ (2014) Molecular and cellular regulation of toll-like receptor-4 activity induced by lipopolysaccharide ligands. Front Immunol 5: 473.

131. Miao EA, Andersen-Nissen E, Warren SE, Aderem A (2007) TLR5 and Ipaf: dual sensors of bacterial flagellin in the innate immune system. Semin Immunopathol 29: 275-288.

132. Guiducci C, Gong M, Cepika AM, Xu Z, Tripodo C, et al. (2013) RNA recognition by human TLR8 can lead to autoimmune inflammation. J Exp Med 210: 2903-2919.

133. Huang X, Yang Y (2010) Targeting the TLR9-MyD88 pathway in the regulation of adaptive immune responses. Expert Opin Ther Targets 14: 787-796.

134. Hasan U, Chaffois C, Gaillard C, Saulnier V, Merck E, et al. (2005) Human TLR10 is a functional receptor, expressed by B cells and plasmacytoid dendritic cells, which activates gene transcription through MyD88. J Immunol 174: 2942-2950.

135. Lee SM, Kok KH, Jaume M, Cheung TK, Yip TF, et al. (2014) Toll-like receptor 10 is involved in induction of innate immune responses to influenza virus infection. Proc Natl Acad Sci U S A 111: 3793-3798. 
136. Hatai H, Lepelley A, Zeng W, Hayden MS, Ghosh S (2016) Toll-Like Receptor 11 (TLR11) Interacts with Flagellin and Profilin through Disparate Mechanisms. PLoS One 11: $\mathrm{e} 0148987$.

137. Cho YG, Cho ML, Min SY, Kim HY (2007) Type II collagen autoimmunity in a mouse model of human rheumatoid arthritis. Autoimmun Rev 7: 65-70.

138. Libbey JE, Fujinami RS (2011) Experimental autoimmune encephalomyelitis as a testing paradigm for adjuvants and vaccines. Vaccine 29: 3356-3362.

139. Allenbach Y, Solly S, Gregoire S, Dubourg O, Salomon B, et al. (2009) Role of regulatory $\mathrm{T}$ cells in a new mouse model of experimental autoimmune myositis. Am J Pathol 174: 989-998.

140. Lohse AW, Manns M, Dienes HP, Meyer zum Buschenfelde KH, Cohen IR (1990) Experimental autoimmune hepatitis: disease induction, time course and T-cell reactivity. Hepatology 11: 24-30.

141. Jones DE, Palmer JM, Kirby JA, De Cruz DJ, McCaughan GW, et al. (2000) Experimental autoimmune cholangitis: a mouse model of immune-mediated cholangiopathy. Liver 20: 351-356.

142. Little MA, Smyth L, Salama AD, Mukherjee S, Smith J, et al. (2009) Experimental autoimmune vasculitis: an animal model of anti-neutrophil cytoplasmic autoantibodyassociated systemic vasculitis. Am J Pathol 174: 1212-1220.

143. Tincani A, Gilburd B, Abu-Shakra M, Blank M, Allegri F, et al. (2002) Immunization of naive $\mathrm{BALB} / \mathrm{c}$ mice with human beta2-glycoprotein I breaks tolerance to the murine molecule. Arthritis Rheum 46: 1399-1404. 
Figure 1

\section{IFN- $\beta$}

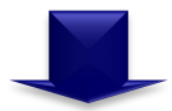

Thymic changes

\section{AChR sensitization}

TEC

$$
\alpha-A C h R
$$

TEC death

Phagocytosis
Cell recruitment

\section{LEC CCL21}

TEC CXCL13 B B

TEC BAFF

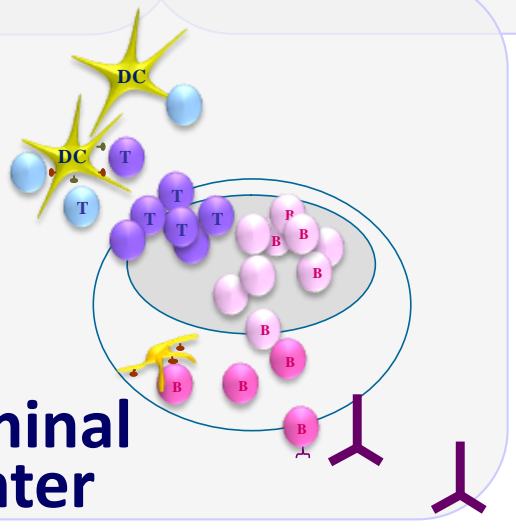

ل AChR attack

Germinal

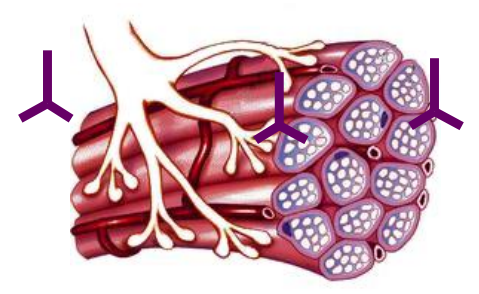


Figure 2

A
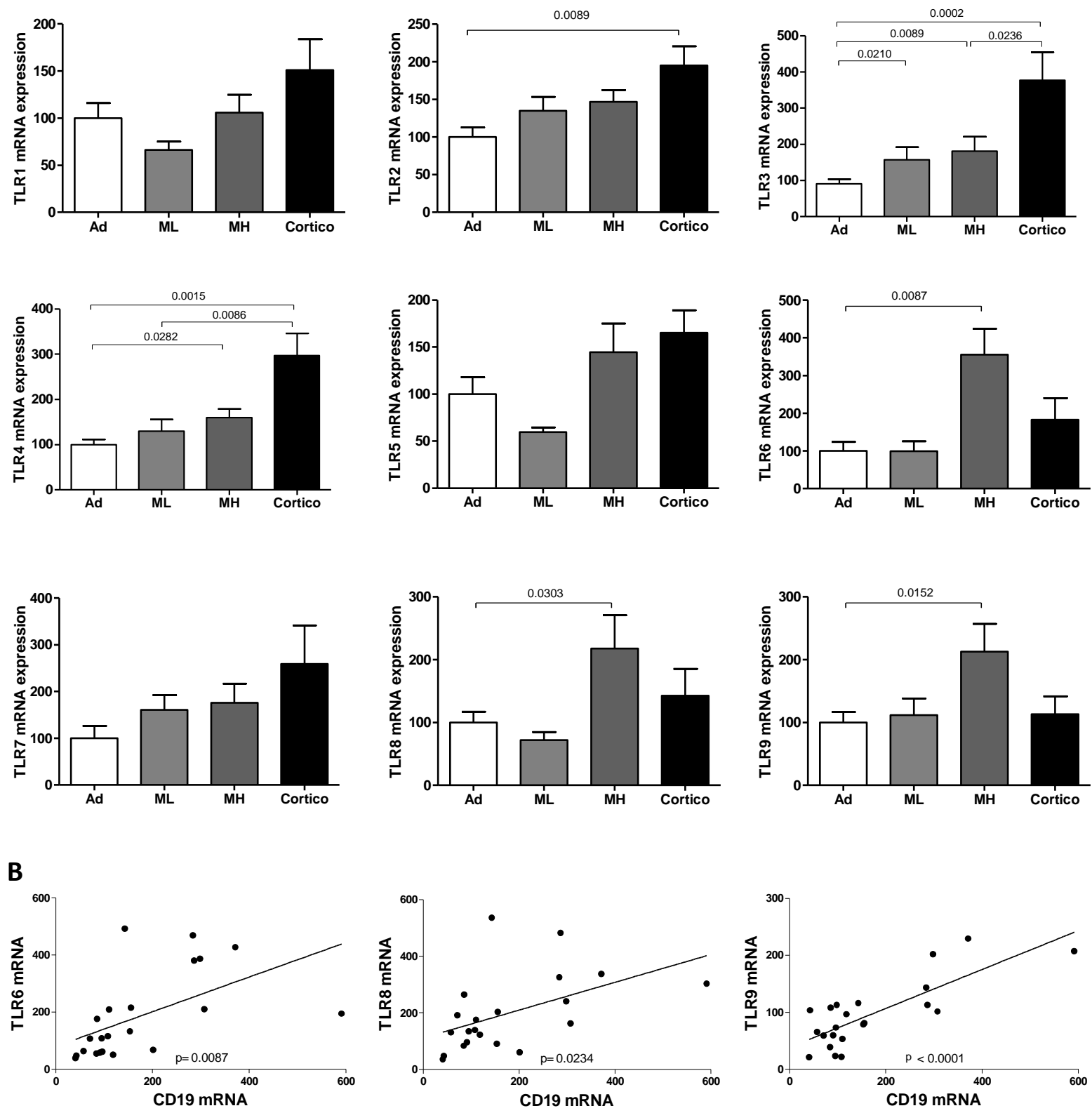